\title{
USE OF EXTERNAL CHARACTERISTICS FOR RAPID IDENTIFICATION OF GENDER OF POCKET GOPHERS
}

\author{
Roger A. Baldwin ${ }^{1,2}$ and Ryan Meinerz ${ }^{1}$
}

\begin{abstract}
AвSTRACT.-Pocket gophers are of great importance both for their function in ecological systems and for their impact on anthropogenic environments. Managing pocket gopher populations requires a fundamental understanding of population demographics, specifically sex ratios; yet quick and reliable techniques for visually identifying gender of pocket gophers are lacking. We developed a visual identification method based on external characteristics of genitalia and mammae that allows for rapid, yet correct assessment of gender in pocket gophers. This approach was particularly accurate (>99\%) for visual identifications in the field. Our approach was also accurate (>98\%) for frozen specimens, although care must be taken when identifying gender of frozen, immature pocket gophers. Although our results pertain specifically to Thomomys talpoides and Thomomys bottae, we believe that our methodology can be broadly applied to additional pocket gopher species.
\end{abstract}

Resumen.-Las tuzas son de gran importancia tanto por su función en los ecosistemas como por su impacto en ambientes antropogénicos. El manejo de las poblaciones de tuzas requiere un conocimiento esencial de la demografía de la población, especialmente la proporción de sexos. Sin embargo, no contamos con técnicas rápidas y fiables para la identificación visual del sexo de las tuzas. Hemos desarrollado un método de identificación visual basado en características externas de los genitales y mamas que permite la evaluación rápida y correcta del género. Este enfoque fue particularmente preciso $(>99 \%)$ para identificaciones visuales en campo. Nuestro enfoque también fue preciso $(>98 \%)$ para muestras congeladas, aunque se debe tener cuidado al identificar el género de las tuzas inmaduras congeladas. Aunque nuestros resultados son específicamente de Thomomys talpoides (Tuza Norteña) y de Thomomys bottae (Tuza de Bota), creemos que nuestra metodología puede aplicarse, en términos generales, a otras especies de tuzas.

Pocket gophers have long been lauded for their function as ecosystem engineers through their extensive tunneling efforts (Huntly and Inouye 1988, Reichman and Seabloom 2002). These tunnel systems serve as important travel corridors and homes for other wildlife species (Vaughan 1961). Additionally, pocket gopher tunneling and mounding activities help in the aeration and fertilization of soils (Mielke 1977, Huntly and Inouye 1988, Reichman and Seabloom 2002), and where found, pocket gophers are a valuable part of the ecological food web (Franklin 1988, Van Vuren et al. 1998). That said, pocket gopher tunneling activity is a hazard to the stability of dams, dikes, and levees (Scheffer 1931, Ordeñana et al. 2012) and can increase losses of water and soil erosion (Scheffer 1931, Reichman and Seabloom 2002). Mounds are a frequent concern for farm equipment; they lead to increased plant mortality through direct burying; and they cause aesthetic concerns and potential hazards for recreational users of parks, athletic fields, and school grounds (Scheffer 1931, Baldwin et al. 2014). Additionally, pocket gophers can cause substantial losses to a variety of crops (e.g., $43 \%-46 \%$ reduction in alfalfa yield-Luce et al. 1981; 25\% reduction in rangeland yieldsFitch and Bentley 1949) through direct consumption of root systems, vegetative material, and tree and vine cambium; and they frequently damage irrigation systems (Baldwin et al. 2014). In short, pocket gophers are of great importance both for their function in ecological systems and for their impact on anthropogenic environments.

Managing pocket gopher populations requires a fundamental understanding of population demographics. A crucial key to understanding these population-level factors is the ability to identify the gender of individuals in a population. Without an ability to identify gender, we cannot build population models, assess reproductive rates, or assess the impact of management programs. For rodents, pubic

\footnotetext{
${ }^{1}$ Department of Wildlife, Fish, and Conservation Biology, One Shields Ave., University of California, Davis, CA 95616.

2E-mail: rabaldwin@ucdavis.edu
} 


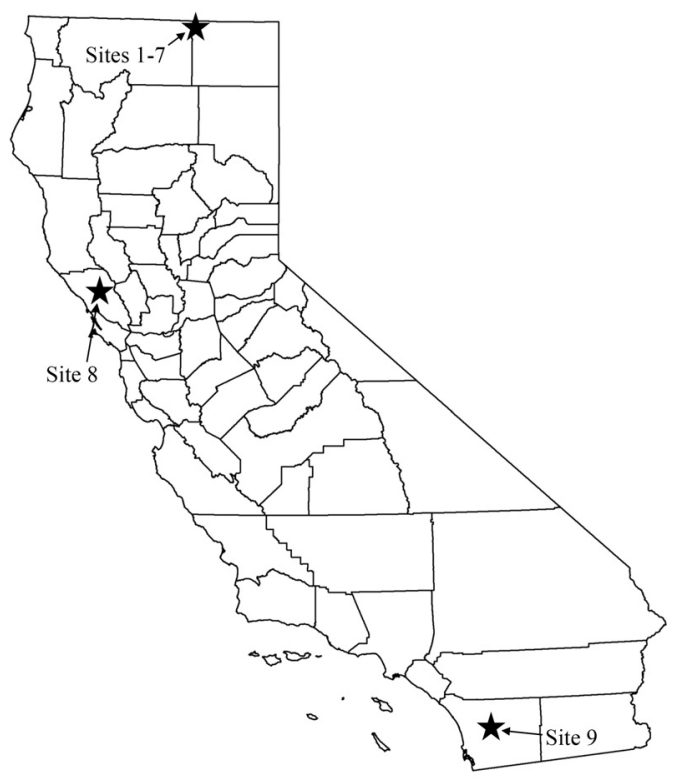

Fig. 1. Nine field sites in California where we assessed the ability to identify gender of Thomomys talpoides (sites 1-7) and Thomomys bottae (Sites 8-9) by using external reproductive characteristics.

gap and presence of external male genitalia often are used to identify gender (e.g., Pugh et al. 2003), yet this approach has not always proven effective in pocket gophers (Witmer et al. 1996), whose fusiform shape allows them to turn around in narrow tunnels. This adaptation has led to the reduction or elimination of an external scrotum in nonreproductive males and has led to the greatly reduced pelvic girdle in males and females. In fact, the ischiatic vacuity is too small to allow for birth of the young, thereby necessitating the reabsorption of the pubic symphysis in females before mating occurs (Hisaw 1924, 1925). As such, an assessment of the ventral side of the pubic symphysis has been suggested to be fairly effective at discerning gender in pocket gophers, but it is obviously less effective on immature females for which the pubic symphysis has not been reabsorbed (Baker et al. 2003). Connior and Risch (2009) suggested that a combination of external characteristics, including genitalia and mammae, were effective at identifying gender of Ozark pocket gophers (Geomys bursarius ozarkensis). We thought this approach was worth pursuing further, given the reported utility combined with the relatively minimal training that would be required for an individual to correctly assess gender of captured pocket gophers. Therefore, our objective was to develop a visual identification method based on external characteristics of genitalia and mammae that would allow for rapid, yet accurate assessment of gender in pocket gophers. Such a visual identification method would greatly aid efforts to research and manage these fossorial species.

\section{Methods}

\section{Study Animal Distribution}

We collected 2 species of pocket gophers (Thomomys talpoides and Thomomys bottae) across 9 different sampling locations throughout California (Fig. 1). Thomomys talpoides was collected in alfalfa (Medicago sativa) fields in Modoc County during April 2012 (sites 1-3) and March-April 2013 (sites 4-7); T. bottae was collected in a vineyard in Sonoma County during April 2013 (site 8) and in a pasture in San Diego County during March 2013 (site 9; Fig. 1).

\section{Capture and Classification of Gender}

We captured all pocket gophers for this study using Gophinator $(n=624$; Trapline Products, Menlo Park, CA) and Topcat $(n=$ 11; Andermatt Biocontrol AG, Grossdietwil, Switzerland) traps. These capture efforts were part of several different studies that assessed ways to utilize and improve trapping as a method to monitor and manage pocket gopher populations. We identified gender of pocket gophers through visual observation of external reproductive characteristics.

We focused our initial observations on the presence of descended testicles. If testicles were not obvious, we looked closely for the presence of mammae. If mammae were not immediately obvious, we gently blew on the fur along the ventral side of the pocket gopher, particularly adjacent to the back legs, to look for small mammae. Even in nonreproductive females, very small mammae were visible upon close inspection. If mammae were present, we identified the pocket gopher as a female. If mammae were not present, we identified the individual as a male. We developed confidence categories, which included "certain," "likely," and "possible," to assist us in assessing the success of our gender classifications. If obvious descended testicles or 
large mammae were present, the individual was placed into the "certain" category (Fig. 2B, 2D). If testicles appeared to be slightly descended, or if fairly small but somewhat apparent mammae were present, the individual was classified as "likely" (Fig. 2A, 2C). If the pocket gopher showed no sign of descended testicles and mammae were either very small or not present, the individual was classified as "possible" (i.e., very small mammae present $=$ female, no mammae present $=$ male). Occasionally, pocket gophers were very dirty, bloody, or wet from trapping or scavenging events, which made gender identification of less obvious individuals (i.e., "possible" category) very difficult. We classified genders of these individuals as "unknown."

To maintain consistency throughout the study, only the lead author recorded visual observation of gender. The gender of all pocket gophers was either identified at the time of capture, or specimens were preserved via freezing and later thawed for identification in the lab. All captured pocket gophers were stored in plastic bags, labeled, and frozen for internal examination of gender at a later date. For internal examination, we completely thawed all specimens. Once specimens had thawed, we opened the abdominal cavity with a scalpel and assigned gender based on identification of sexual organs. We also examined all unknown samples to determine if unknowns were skewed toward one gender. All trapping procedures were approved by the University of California, Davis, Animal Care and Use Committee (protocol numbers 15763, 16915, and 17283).

\section{Statistical Analysis}

We used the exact binomial test to determine if the gender ratios differed between $T$. talpoides and T. bottae (McDonald 2009). We used Fisher's exact tests (i.e., tests of independence) to determine if the rate of successful classification differed across confidence categories for the 2 pocket gopher species within gender classifications and within field and frozen samples (Zar 1999). If significant differences were observed, we used multiple Fisher's exact tests to determine which confidence categories differed. We used the Cochran-Mantel-Haenszel (Cochran 1954, Mantel and Haenszel 1959) test to determine potential differences in classification success between males and females, field and frozen specimens, and species. This approach allowed us to test for differences between these factors while accounting for potential differences across confidence categories.

\section{RESUlTs}

During spring 2012 and 2013, we visually inspected 633 pocket gophers for gender (479 T. talpoides, 154 T. bottae). Of these, 373 were inspected in the field and 260 were frozen for analysis (Table 1). We observed more $T$. talpoides males $(n=294)$ than females $(n=$ 181; exact binomial test $P<0.001$ ); $T$. bottae captures were skewed toward females (64 males, 89 females, exact binomial test $P=$ $0.052)$. Unknowns were relatively uncommon $(n=28)$ and were not skewed toward male or female (T. talpoides: 6 males, 7 females, exact binomial test $P=1.0 ;$ T. bottae: 7 males, 8 females, exact binomial test $P=1.0$ ).

Based on external characteristics, we correctly identified the gender of all but 5 pocket gophers (4 T. talpoides, $1 \mathrm{~T}$. bottae), with all but one of the failed identifications occurring in the "possible" category (Table 1). Only one of the misidentifications was a male pocket gopher, suggesting that identification of females may be slightly more difficult. We observed a difference in the proportion of frozen T. talpoides correctly identified as male across the 3 confidence categories (Fisher's exact test $P<0.001$; Table 1). This difference occurred between the "certain" and "possible" (Fisher's exact test $P=0.001$ ) and "likely" and "possible" (Fisher's exact test $P=0.008$ ) categories, suggesting that identifying genders of pocket gophers of less apparent reproductive status may be challenging for frozen samples. We did not observe any other differences across the 3 confidence categories for either species or for frozen or field observations (Fisher's exact test $P=1.0$ ). We also did not observe a difference in the classification success of gender identification between males and females $\left(\chi^{2}{ }_{1} \leq 0.15\right.$, $P \geq 0.703)$, field and frozen samples $\left(\chi^{2}{ }_{1} \leq\right.$ $0.27, P \geq 0.605)$, or species $\left(\chi^{2}{ }_{1} \leq 0.02, P \geq\right.$ $0.876)$. However, we did observe a greater proportion of frozen pocket gophers with unknown genders compared to those observed in the field (frozen: 19 out of 260, field: 9 out of 373; Fisher's exact test $P=$ $0.005)$, indicating that freezing pocket gophers 


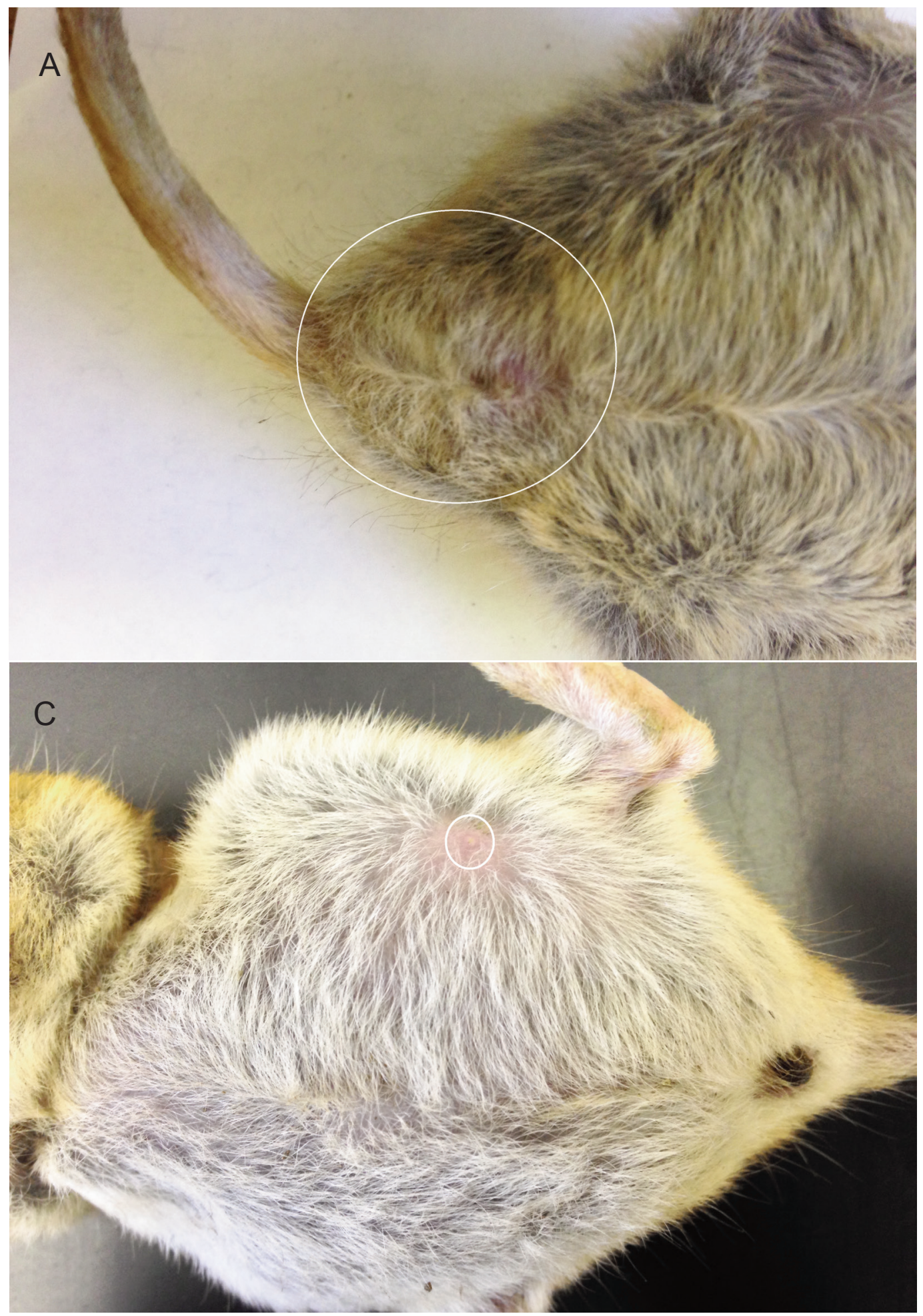

Fig. 2. Examples of the external morphological characteristics we used to identify male (A, nonreproductive [analogous "likely" category]; D, reproductive [analogous to "certain" category]) pocket gophers. For males, white circles denote 


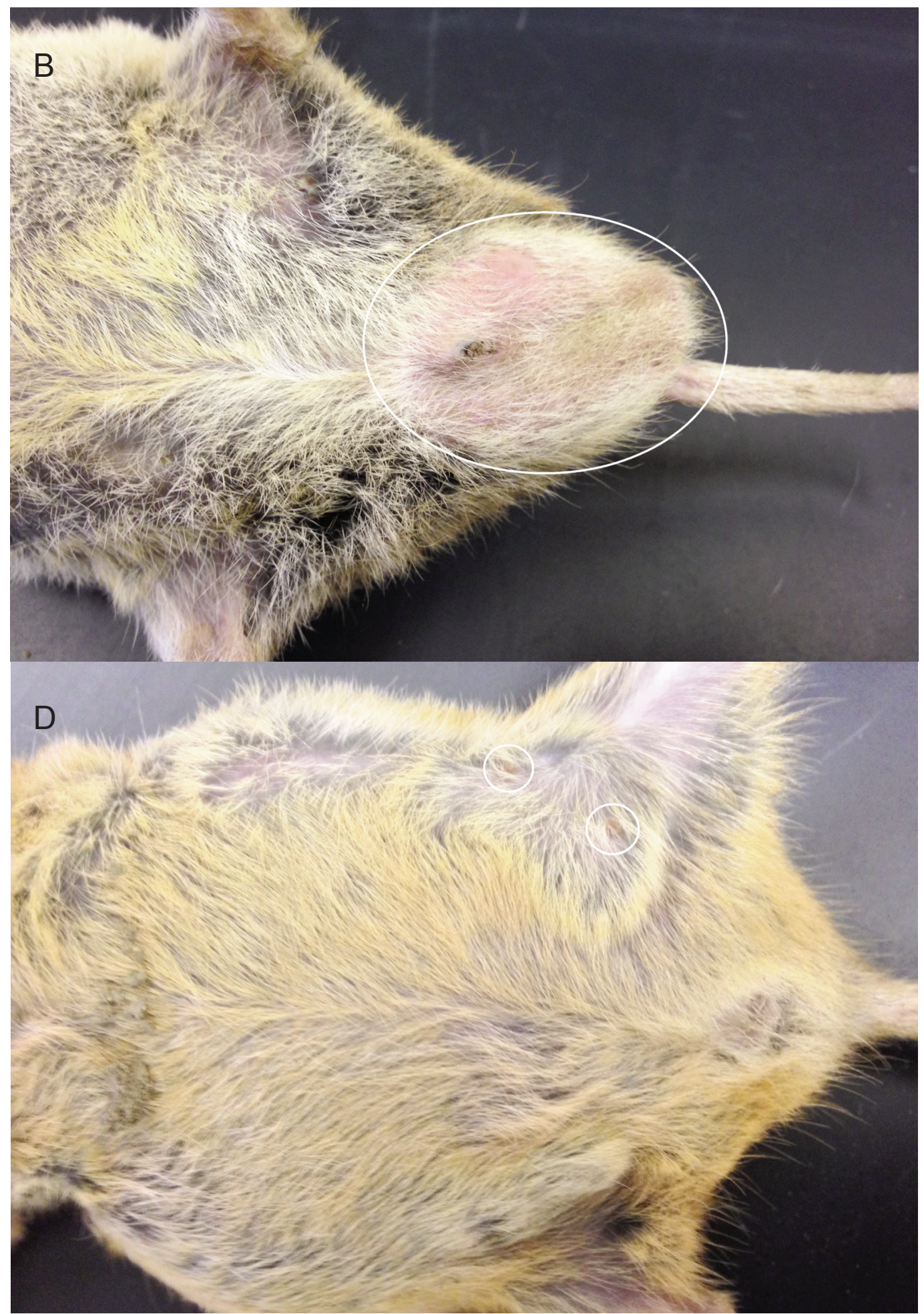

to "likely" category]; B, reproductive [analogous to "certain" category]) and female (C, nonreproductive [analogous to pocket gophers with and without descended testes. For females, white circles point out mammae. 


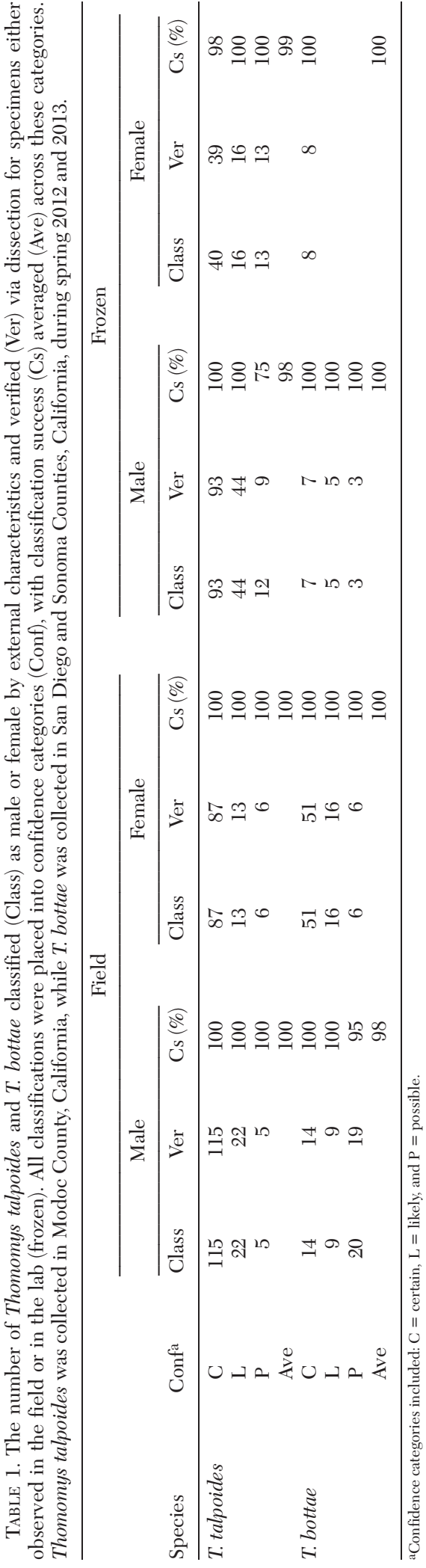

can make gender identification more challenging. Still, we observed high classification rates even with frozen pocket gophers (Table 1).

\section{Discussion}

Correct identification of gender in pocket gophers has historically been challenging. Baker et al. (2003) indicated that males could be identified by feeling for an elevated peak along the ventral side of the pubic symphysis; mature females would exhibit a narrow trough rather than this peak. However, this trough may not be present in immature females, making the efficacy of this approach somewhat variable. Additionally, assessing the pelvic girdle requires specialized training and can be somewhat difficult to perform on live, nonsedated individuals. Palpation of baculum and pubic gap is often used for other rodent species and has been used for pocket gophers (Howard and Childs 1959), but was shown to be relatively inaccurate for Thomomys mazama (22\% error rate; Witmer et al. 1996). We found that by looking for descended testicles and mammae, we were highly successful at identifying the gender of both T. talpoides and T. bottae (only 5 out of 633 pocket gophers misclassified). Furthermore, this approach is very simple and can be performed with only basic training.

We observed a greater proportion of males in the T. talpoides populations sampled but a greater proportion of females in T. bottae specimens. This could have influenced our results if one gender was easier to identify. However, given the small percentage $(<1 \%)$ of individuals that were misclassified, we could detect no significant differences in classification success across genders. That being said, we did note that only one male was misclassified. Distinguishing females from males may be slightly more difficult when assessing gender of small, immature individuals; extra diligence should be used when searching for mammae on very small individuals to maximize classification success.

The obviousness of descended testicles and mammae appeared to have little influence on our ability to successfully classify the gender of pocket gophers in the field, indicating that this approach is robust across all age classes of pocket gophers that were sampled (correct classification percentage: $100 \%$ T. talpoides, $>99 \%$ T. bottae). It should be noted that all 
samples were collected in March and April. It is possible that samples collected at different times of the year may be more difficult to identify. However, pocket gophers typically breed at various intervals throughout the year (Baker et al. 2003). Therefore, individuals of various reproductive stages should be present in a population throughout most of the year. Also, we sampled pocket gophers from various locations throughout the state of California. This spatial variation should have mitigated any potential impact that might have occurred if we had sampled during a reproductive pulse at one location. Furthermore, classification success was very high across all confidence categories. Therefore, even if sampling occurred during a period when reproduction was minimal in the population, we would still expect to see high classification percentages in the field given the success we observed in classifying individuals with relatively nondescript identification features.

Interestingly, for frozen specimens, distinguishing males and females was more difficult when deterministic morphology was less obvious, as we occasionally misclassified females as males. Additionally, we observed a greater proportion of frozen specimens for which we could not identify gender. When pocket gophers are frozen and subsequently thawed, condensation often wets the ventral side of the specimen. This water mixes with dirt and potentially blood found on the pocket gopher or in the bag, making identification of small, nondescript mammae difficult. A thorough cleansing and drying of the specimen may increase ability to correctly identify gender, but requires substantial time. In these situations, a necropsy would provide an accurate, less time-consuming option for gender identification.

We acknowledge that it may not always be feasible or practical to identify gender of pocket gophers in the field. Therefore, it should be stressed that misclassification of frozen samples was problematic only for specimens where descended testicles and obvious mammae were not present (i.e., the "possible" category); the overall correct classification percentage for frozen samples was still $>98 \%$ for T. talpoides and $100 \%$ for T. bottae. Paying special attention to frozen pocket gophers that have been thawed but exhibit nondescript identification features should reduce the potential for misclassification. Nonetheless, when possible, the assessment of gender in the field should provide greater classification success.

It should be noted that these results pertain to dead pocket gophers. Close inspection is required to identify gender of immature individuals, which can be difficult when handling live, mobile pocket gophers given the loose skin around their head and neck which makes them difficult to grasp. One potential option to mitigate potential handling difficulties is to grasp pocket gophers by the tail and around the nape of the neck, thereby making assessment of reproductive characteristics more manageable. Another option would be to sedate individuals, but existing regulations on immobilization chemicals, as well as potential animal welfare concerns, could limit this approach. These factors will need to be considered when determining the appropriate gender-identification strategy for specific situations; to better address this issue, additional study on the utility of our defined genderidentification approach for live pocket gophers is warranted.

Our results pertain specifically to $T$. talpoides and T. bottae. Further testing on other species of pocket gophers is warranted to determine the utility of this visual approach. However, given the high classification success rates we observed, combined with the success observed following a similar approach for G. bursarius ozarkensis (Connior and Risch 2009), we anticipate that our methodology will be useful for additional pocket gopher species.

\section{ACKNOWLEDGMENTS}

We thank S. Orloff and various staff at the University of California Intermountain Research and Extension Center for assistance in trapping pocket gophers. We also thank S. Ausburn and Gallo Family Vineyards, J. Castro and the Pala Band of Mission Indians, and numerous alfalfa growers in Modoc County, California, for allowing us access to their property for trapping operations. Two anonymous reviewers provided beneficial comments to strengthen this manuscript. Partial funding for this project was provided by the University of California Statewide Integrated Pest Management Program. 


\section{Literature Cited}

Baker, R.J., R.D. Bradley, and L.R. McAliley Jr. 2003. Pocket gophers. Pages 276-287 in G.A. Feldhamer, B.C. Thompson, and J.A. Chapman, editors, Wild mammals of North America. Johns Hopkins University Press, Baltimore, MD.

Baldwin, R.A., T.P. Salmon, R.H. SChmidt, and R.M. Tiмm. 2014. Perceived damage and areas of needed research for wildlife pests of California agriculture. Integrative Zoology 9:265-279.

Cochran, W.G. 1954. Some methods of strengthening the common $\chi^{2}$ tests. Biometrics 10:417-451.

CONNIOR, M.B., AND T.S. Risch. 2009. Live trap for pocket gophers. Southwestern Naturalist 54:100-103.

Fitch, H.S., and J.R. Bentley. 1949. Use of California annual-plant forage by range rodents. Ecology 30: 306-321.

Franklin, A.B. 1988. Breeding biology of the Great Gray Owl in southeastern Idaho and northwestern Wyoming. Condor 90:689-696.

Hisaw, F.L. 1924. The absorption of the pubic symphysis of the pocket gopher, Geomys bursarius (Shaw). American Naturalist 58:93-96.

Hisaw, F.L. 1925. The influence of the ovary on the resorption of the pubic bones in the pocket gopher, Geomys bursarius (Shaw). Journal of Experimental Zoology 42:411-441.

Howard, W.E., AND H.E. ChILDS Jr. 1959. Ecology of pocket gophers with emphasis on Thomomys bottae mewa. Hilgardia 29:277-358. dx.doi.org/10.3733/hilg .v29n07p277

Huntly, N., And R. InOuye. 1988. Pocket gophers in ecosystems: patterns and mechanisms. BioScience 38:786-793.

Luce, D.G., R.M. Case, and J.L. Stubbendieck. 1981. Damage to alfalfa fields by plains pocket gophers. Journal of Wildlife Management 45:258-260.

Mantel, N., and W. Haenszel. 1959. Statistical aspects of the analysis of data from retrospective studies of disease. Journal of the National Cancer Institute 22:719-748.

McDonaLD, J.H. 2009. Handbook of biological statistics. Sparky House Publishing, Baltimore, MD.

MielKe, H.W. 1977. Mound building by pocket gophers (Geomyidae): their impact on soils and vegetation in North America. Journal of Biogeography 4:171-180.

Ordeñana, M.A., D.H. Van Vuren, and J.P. Draper. 2012. Habitat associations of California ground squirrels and Botta's pocket gophers on levees in California. Journal of Wildlife Management 76: 1712-1717.

Pugh, S.R., S. Johnson, and R.H. Tamarin. 2003. Voles. Pages 349-370 in G.A. Feldhamer, B.C. Thompson, and J.A. Chapman, editors, Wild mammals of North America. Johns Hopkins University Press, Baltimore, MD.

Reichman, O.J., and E.W. SEabloom. 2002. The role of pocket gophers as subterranean ecosystem engineers. Trends in Ecology and Evolution 17:44-49.

Scheffer, T.H. 1931. Habits and economic status of the pocket gophers. United States Department of Agriculture Technical Bulletin 224:1-26.

Van Vuren, D., T.G. Moore, and C.A. Ingels. 1998. Prey selection by Barn Owls using artificial nest boxes. California Fish and Game 84:127-132.

VAUGHAN, T.A. 1961. Vertebrates inhabiting pocket gopher burrows in Colorado. Journal of Mammalogy 42:171-174.

Witmer, G.W., R.D. SaYler, and M.J. Pipas. 1996. Biology and habitat use of the Mazama pocket gopher (Thomomys mazama) in the Puget Sound Area, Washington. Northwest Science 70:93-98.

ZAR, J.H. 1999. Biostatistical analysis. 4th edition. PrenticeHall, Upper Saddle River, NJ.

Received 11 September 2014 Accepted 7 April 2015 